\title{
Regulating Foreign Labor in Emerging Economies: Between National Objectives and International Commitments
}

\author{
Aries Harianto \\ Universitas Jember, \\ Jalan Kalimantan No. 37, \\ Kampus Tegal Boto, Jember, \\ Jawa Timur 68121, Indonesia
}

DOI: https://doi.org/10.36941/ajis-2021-0092

Abstract

The dialectics of the regulation of foreign workers, is a problematic indication as a legal problem in Indonesian legislation. This article aims to describe the urgency of critical studies concerning the regulation of foreign workers by exploring existing legal problems with national commitments to ratify international agreements regarding free trade, with a case study in Indonesia. By using normative and juridical approach with a variety of approaches both the law approach, conceptual approach, case approach and comparative approach, the study found that the regulation there is an inconsistency clause regarding special competencies that must be owned by foreign workers, including the selection and use of terminology in Act No. 13 of 2003 concerning Manpower. Thus, this study offers a constitutional solution due to the regulation of the subordinate foreign workers on international trade commitments which in turn negate the constitutional goals of creating the welfare of domestic workers. The normative consequences that immediately bind Indonesia after integrating itself in the World Trade Organization (WTO) membership are services trade agreements that are contained in the regulations of the General Agreement on Trade in Services (GATS). Based on the GATT/WTO rules, national legislation or labor regulations that are too protective are considered to violate WTO provisions because the WTO substantially requires the creation of policies without discrimination in all matters including equalizing the position of foreign workers and domestic workers. The final finding of this study offers to draft the concept of future regulation regarding the regulation of foreign workers who are loaded with elements of the objectives of constitutional-based law.

Keywords: legal problem, coherence, constitutional rights, foreign workers

\section{Introduction}

Laborers, and especially the presence of foreign workers, has become a topic of much debate by prominenters and academics. Although several studies show that the problem of foreign workers is also a serious problem in Asian developed countries, such as Japan, Singapore and South Korea due to their compromise in accepting immigrants (Yamanaka, 1993; Lie, 1994; Boswell \& Straubhaar, 2004; Herbert, 2010; Fong, 1992; Kim, 2003), in developing countries, both Asian middle-upper and middlelower income countries, with relatively high unemployment rates, the presence of foreign workers is considered to seize the employment of local citizens (Noor et al., 2011; Salleh et al., 2012; Abdul-Rahman 
et al., 2012; Abdul-Aziz, 2001). Due to this high level of social resistance, many developing countries impose rules that limit the types of work that foreign workers can occupy. In addition, developing countries are still considered less committed to international rules regarding labor and capital flows, goods and services (see more, Cohen, 2016). This makes the implementation of free trade not run optimally because of the imbalance between countries in trade and the flow of resources, especially if trade is carried out between developing countries and developed countries. As a case in Indonesia, the issue of foreign workers is not only economically charged, but also political. This is because regulations that allow the presence of foreign workers are considered not in favor of providing employment for Indonesian citizens.

In the context of the flow of labor, Asia's lower middle income countries, such as Indonesia, the Philippines, Pakistan, India and Bangladesh tend to fill more jobs in more developed countries, such as Singapore, Malaysia, Hong Kong, Taiwan and South Korea and Middle East richest countries (Kanapathy, 2006; Kaur, 2005; Kapiszewski, 2017; Elias, 2018). This compares with the amount of work that these countries can offer foreign citizens. This is because of the limited number of white-collar jobs that citizens of developed countries usually want. In addition, most of the work in developed countries by developing country workers is to fill low-paying jobs such as domestic and construction works (Yen et al., 2015). Therefore, by regulation, labor provider countries will tend to be protective in accepting foreign workers in their countries, and will tend to put pressure on employer countries to protect their citizens more (see, Chin, 1997; Killias, 2010; Elias, 2018). As a result, there is an imbalance between the willingness to accept the flow of labor, and the commitment of each party to accept international rules related to labor (Liow, 2003; Liow, 2017).

One of the national development missions for 2005 - 2025 is to realize Indonesia plays an important role in the international community. This mission is operationalized in the form of strengthening Indonesian diplomacy to encourage international cooperation, in various fields, including trade. While the mission in the field of law, one of which is the establishment and enforcement of laws that favor the small people. This means that legal development in Indonesia must be oriented towards protection, without negating international interests. Since 12 November 1994, Indonesia has agreed to the establishment of the WTO. This agreement was later institutionalized in the form of ratification through Law Number 7 of 1994 concerning the Ratification of the Agreement Establishing The World Trade Organization as contained in the State Gazette of the Republic of Indonesia Number 1994 Number 57. Referring to the provisions of the law The law meant that Indonesia had complied with the agreement stated in the Final Act and had ratified the General Agreement on Tariff and Trade (GATT) on December 2, 1994. The next consequence, since December 2, 1994, Indonesia officially became a member of the WTO. Thus, the existing attachment has placed Indonesia to submit to and comply with the provisions in the WTO institution besides being prepared to accept the legal consequences that arise within the framework of implementing regulations stipulated by the WTO.

Table 1. Foreign workers in Indonesia and Indonesian migrant workers

\begin{tabular}{|c|c|c|c|c|}
\hline \multirow{2}{*}{ Year } & \multicolumn{3}{|c|}{ Foreign Workers in Indonesia } & \multicolumn{2}{c|}{ Indonesian Migrant Workers } \\
\cline { 2 - 5 } & Number & Change (\%) & Number & Change (\%) \\
\hline 2015 & 77,149 & - & 275,736 & - \\
\hline 2016 & 80,375 & 4.18 & 234,451 & $-14,97$ \\
\hline 2017 & 85,974 & 4.37 & 261,820 & 11.67 \\
\hline
\end{tabular}

Source: www.indonesia-investments.com from Manpower Ministry (for foreign workers) and www.ilo.org from Siskotkln BNP2TKI (for migrant workers). 
Table 2. Origin of Foreign Workers in Indonesia and IMW by Country of Destination (2017)

\begin{tabular}{|c|c|c|c|}
\hline \multicolumn{2}{|c|}{ Origin } & \multicolumn{2}{c|}{ Destination } \\
\hline Country & Number & Country & Number \\
\hline China & 24,804 & Malaysia & $\mathbf{2 7 4 , 2 2 8}$ \\
\hline Japan & 13,540 & Taiwan & $\mathbf{2 1 5 , 2 1 4}$ \\
\hline South Korea & 9,521 & Hongkong & 97,859 \\
\hline India & 6,237 & Singapore & 51,974 \\
\hline Malaysian & 4,603 & Saudi Arabia & 43,009 \\
\hline Philippines & 3,174 & Brunei Darussalam & $\mathbf{2 4 , 7 6 8}$ \\
\hline Australia & 2,603 & South Korea & 15,141 \\
\hline United States & 2,526 & UAE & 11,861 \\
\hline United Kingdom & 2,016 & Oman & 8,865 \\
\hline Singapore & 1,915 & Qatar & 4,852 \\
\hline Others & 15,035 & Others & 24,236 \\
\hline
\end{tabular}

Source: www.indonesia-investments.com from Manpower Ministry (for foreign workers) and www.ilo.org from Siskotkln BNP2TKI (for destination).

The legal provisions that directly bind Indonesia after entering into a member of the WTO are related to the services agreement stipulated in the provisions of the General Agreement on Trade in Services (GATS). In the GATT/WTO perspective legislation in the field of labor that is too protective of Domestic Workers is considered to violate the provisions of WTO law. The WTO is committed to policies without discrimination in all matters including efforts to equalize the position of foreign workers and domestic workers in this case the workers in them.

Indonesia is a sovereign country where it is permissible to apply several barriers to its trade relations, provided that it does not violate international law and also the sovereignty limits. In this conception, as one of the countries that has ratified the WTO rules and policies, it is necessary to protect access to the employment sector. Besides that, the opening of market access by developing countries is highly desired by developed countries, because this can encourage the acceleration of free trade, which means there is no discrimination against a product or service originating from any country. This condition is confirmed by the existence of the ASEAN Economic Community. Since January 2016, as a consequence of its implementation, the ASEAN Economic Community has opened the space for globalization of goods, services including labor. Such a situation is a factor in the increasing statistics of foreign workers entering the workforce in Indonesia. Based on existing regulations, not all foreign workers can enter and fill all fields of work in Indonesia. The qualifications of foreign workers who are allowed to enter Indonesia are foreign workers who have special skills and professionals in their fields.

As it is known that the purpose of implementing labor law in Indonesia is to guarantee and provide certainty of decent employment opportunities for Indonesian citizens in various fields and levels within the framework of state goals as mandated by the 1945 Constitution of the Republic of Indonesia. Based on the intended constitutional commitment, efforts to open doors for foreign workers in Indonesia are carried out in the form of strict mechanisms and procedures, through the process of selection, licensing and supervision. Law 13 of 2003 concerning Labor, is specifically concerning the regulation of foreign workers, its existence has revoked Law No. 3 of 1958 concerning placement of foreign workers in Indonesia. In Chapter VIII specifically Articles 42 to 49 Labor Laws is a basic reference in terms of the placement of foreign workers in Indonesia today, plus various implementing regulations as a more operational translation. There are some provisions explicitly stated that Indonesia has commitments to protect basic rights its citizens as a constitutional right to work. Even though legally the existence of foreign workers has been regulated in such a way in national law but 
does not mean that the regulation is meant to be zero problem (Amengual \& Chirot, 2016). Even the existence of foreign workers arrangements as a manifestation of state intervention to open the space for constitutional rights to work must be confronted diametrically with international commitments in the fields of economy and trade dilemma. On the basis of the description above, this paper was written as an academic opinion in the hope of providing concrete contributions in order to find alternative solutions to save constitutional goals under pressure from international commitments. This study aims to formulate the problem of the legal arrangements of foreign workers in Indonesian legal system and the comparation of national commitment and its international commitments regarding legal position of foreign workers in Indonesia.

\section{Legal Problems in Regulating Legal Foreign Workers in the Legal System in Indonesia}

Legal problem is a problem contained in legal norms covering conflict norms, rule vacancies, vagueness of formulation, uncertainty, injustice and the like. In the intended article the term used is 'labor'. Academically, terms of Labor, Workers, Labor have differences. Based on Labor Laws, it is understood that the definition of Labor is anyone who is able to do work to produce goods and/or services both to meet their own needs and for the community. While the definition of workers in the same law is everyone who works by receiving wages or other forms of compensation (Article 1 number (3) of Law No.13 of 2003). The term labor used in Article 46 to 49 Labor Law can be understood as a person who has the potential to work. It is explicitly stated in Labor Laws Article 42 paragraph (4) that, 'foreign workers can be employed in Indonesia only in employment relations for certain positions and at certain times.'

Work relations according to the same law as stipulated in Article 1 number 15 are "relations between employers and workers based on work agreements, which have elements of work, wages, and orders." Thus it can be understood that foreign workers working in Indonesia are limited to the existence of employment relations which in turn positions the foreign workers as foreign workers. Its legal consequences, the regulation of foreign workers in Article 42 paragraph (4) in the Law is intended to regulate foreign workers who work in work relations. Labor Laws do not regulate matters concerning independent workers (not bound to work relations). In other words Labor Laws does not regulate painters, artists, lawyers and foreign professionals who are not bound by work relations. This fact is an indication of the rule void (vagenorm).

Other issues that are quite important and basic as a note, foreign workers work within the limits of work relations. Legally, the restrictions on foreign workers work relations in accordance with the legislation in force have quite a lot of weaknesses. This weakness mainly concerns the time limit of employment relations, which in turn provides the opportunity to open up opportunities for foreign workers to work forever in Indonesia. Such a situation ultimately closes the possibility of technology transfer and expertise for Indonesian workers as domestic workers. Referring to Article 42 paragraph (4) of the Law, it is stated that foreign workers can be employed in Indonesia only for certain positions and in certain time or non-permanent employment relationships. However, the regulation concerning foreign workers in Labor Laws Chapter VIII does not mention, moreover, further emphasize the employment relationship of foreign workers when there is a violation of the Specific Time Work Agreement (PKWT). While on the other hand the Labor Laws allow the transfer of PKWT to become a Specific Time Work Agreement (PKWTT) as a legal consequence when there is a violation of PKWT provisions that do not differentiate between domestic workers and foreign workers.

If based on Labor laws, legally foreign workers can only be employed in a certain time-working relationship status (PKWT), but because there has been a violation of the PKWT, the working relationship of foreign workers can switch status to an indefinite time-based worker or PKWTT. In other words, it can be understood that Labor Laws still opens opportunities for employers to continue to use foreign workers without time limits. The gap is found in Article 59 Labor Laws. Even through Article 59 Labor Laws, functionally it can be used as a mode for employers or employers in an effort to place foreign workers as permanent workers. With the pretext of violation of Article 59 of Labor Laws, 
employers can immediately make permanent workers status for foreign workers. Therefore, this article needs to be amended in order to provide labor protection for domestic workers.

Then a legal issue emerged, with the change in the status of Indonesian migrant workers who became PKWTT due to violations of the provisions of the PKWT, is the existence of the intended foreign workers entitled to severance pay? It should be noted, at the practice level, the Supreme Court judge has expressed his opinion that severance pay is only the right of workers in the status of permanent employment relationship or PKWTT. Thus it is understood that foreign workers employed in PKWT status do not have the right to get severance pay. The Decidendi ratio of such decisions can be understood through the Decision of the Supreme Court Number $286 \mathrm{~K} / \mathrm{Pdt}$.Sus-PHI/2013. The verdict was born due to a dispute between foreign workers who were employed PKWT without interruption for approximately 13 years and then were laid off. In his opinion, the Supreme Court stated that compensation for layoffs in the form of severance pay was not entitled to be received by foreigners in their capacity as foreign workers. Comparatively, the Supreme Court Decision No. 595K/Pdt.SusPhi/2010 can also be observed. In the ruling, the Jakarta Industrial Relations Court decided the status of foreign workers with Specific Time Work Agreement (PKWT) changed to permanent worker status (Indefinite Time Work Agreement/PKWTT) because the existence of a work agreement that was not fulfilled by employers involved aspects of PKWT which should also be made in Indonesian. This provision was violated by employers so that the status of the foreign workers PKWT became PKWTT. Because he turned into a permanent worker, the court stated in his decision that foreign workers was entitled to receive severance pay. However, the Supreme Court overturned the decision. The Supreme Court has given a different opinion. Even though PKWT is made only in English which is contrary to the provisions of Article 57 paragraph (1) of the Law, it does not necessarily make the PKWT into PKWTT. According to the Supreme Court, the reason is because the existence of workers is a foreign workers based on Article 42 paragraph (2).

Legal problems that regulate foreign workers have become worse since the enactment of Presidential Regulation No.20 concerning the Use of Foreign Workers (Perpres No.20 of 2018). Article 26 of Presidential Regulation No. 20 of 2018 does not explicitly require foreign worker employers to provide education and training to local workers. In that article the foreign worker employer is only required to appoint a local workforce to be a companion to the foreign workers, but there is no mention of the number who must accompany the foreign workers and be given training by the foreign workers employer. In other words, Presidential Decree No.20 of 2018 does not explicitly state the obligations of foreign workers to transfer jobs and transfer of knowledge to Indonesian migrant workers. Likewise, the adjustment of Indonesian Language is also not in the rules of the new President Decree. Not to mention the mandatory foreign language staff in Indonesian, the ratio of 1:10 (one foreign worker and 1o local workers) was all eliminated. Even in Ministerial Regulation No. 35 of 2016 concerning Procedures for the Use of Foreign Workers, mentioned in Article 26). Such facts certainly contradict Labor Law Article 42 paragraph (4).

\section{Legal Position of Foreign Workers in Indonesia Towards International Commitments}

Basically, foreign workers are not a new problem in the global era. The problem of foreign workers has basically emerged since the start of industrialization in this world. As a result of globalization along with trade liberalization and investment, among others, in the form of direct foreign investment, in turn the consequences of the number of foreign workers working in Indonesia statistically tend to increase. The other side because Indonesia is part of a country that has integrated itself with the WTO, AFTA and APEC, the potential for foreign workers to enter Indonesia from time to time is increasing. One of the scope of WTO management is trade in the service sector (General Agreements on Trade in Services). In the rules of the game, it requires each member country to open up market access for foreign service providers. Indonesia, which has participated as a member of the WTO and has ratified legally, of course must follow the obligations mandated in the agreement.

In the development of the international world today, it is impossible when a country or nation 
does not communicate with other nations or countries. Isolating oneself is an action that inhibits the progress and development of a country from international relations in various fields, both in political, economic, cultural and other interests, including in the field of employment. Now in the era of free trade polarization of trade blocs has been built both at regional and global levels. The World Trade Organization (WTO) at the global level and the ASEAN Free Trade Area (AFTA) at the regional level which has been born is an important and fundamental sign of globalization of world trade. Also included in this case is the globalization of labor. This globalization makes the trade traffic of goods and services and the movement of people become borderless or almost without limits.

Through the General Agreement on Trade in Services (GATS) to develop the expansion of market access in the service sector, it is determined that each country is required to make a liberalization commitment and the implementation of the implementation of 'how much' outside service suppliers can provide services in the national territory . This GATS/WTO Agreement is legally binding and requires compliance with member countries. The legal consequences if there is a member country that violates the agreement then it could be complained by other member countries because they feel disadvantaged. Complaints by these trading partners have the potential to cause the country complained of receiving trade sanctions that have been determined and enforced by the WTO. The WTO can be institutionally very powerful in its authority over member countries by imposing a variety of rules. Every member of the WTO in this case a member state is legally-binding and the decision is irreversible (Ibid).

Basically, labor policy in Indonesia must be directed to provide protection and welfare for Indonesian workers. However, as part of the international community, provisions in the GATS/WTO institution concerning Natural Movement of Persons are important to be accommodated in regulations and policies regarding the placement of foreign workers by looking at the experience of their application in other countries in the interest of protecting Indonesian workers as domestic workers. Based on the normative optics of GATS/WTO, the rule of law regarding labor that is too protective, can be assumed to violate WTO legal rules that require the existence of policies without discrimination in many ways. But if the WTO policy that does not want protection for local workers, as well as discrimination against foreign workers is followed by Indonesia, Indonesian workers will certainly be far behind when they have to compete with foreign workers who have better skills and education.

Job opportunities for all Indonesians are guaranteed by the state. Indonesian people or can also be called Indonesian people is one of the basic capital if it can be fostered and organized and then deployed into an efficient and effective workforce. So it is very clear that the very large number of Indonesia's population will be very important or on the one hand it can also be a social burden on the country if it cannot be used as labor in the framework of development.

In the consideration of the Labor Laws, it is stated that protection of workers is intended to guarantee the basic rights of workers and ensure equal opportunities and treatment without discrimination on any basis to realize the welfare of workers and their families while taking into account the progress of the business world (Lanny 2007). Based on the these provisions, it can be understood that work or work is a manifestation of Constitutional Rights, even Human Rights, hence the sole authority of the state to create employment opportunities is a manifestation of constitutional responsibility. Because of that the government should pay great attention to the procedures for the entry of foreign workers into Indonesia. Restrictions through arrangements are very necessary, but on the other hand, excessive regulation can intersect with the ratification of the General Agreement on Trade in Services (GATS) that has been done "consciously".

Based on these matters, a dilemma arises in the field of employment in Indonesia. On the one hand the application of GATS requires a free market which means foreign workers are free to enter Indonesia. On the other hand, the influx of foreign workers has made job opportunities for Indonesian workers increasingly narrow. Objectively, some Labor Law materials are in line with the GATS principles, although it is also undeniable that the regulation also finds material that is not in line. Noting the fact that the two regulations have become part of the positive legal system in Indonesia, it must be ensured that those that have the force apply. With the capacity as a subsystem that is related 
to one another, then it is fitting for each existing subsystem to support each other and not contradict each other, so that the existence of both can be a useful part of achieving goals in the applicable legal system.

If examined more closely, basically it turns out Law No. 7 of 1994 concerning the Ratification of the Agreement Establishing the World Trade Organization and the Law in absolute terms does not reflect as a subsystem that is harmonious and mutually supportive. This fact builds legal issues, in order to solve problems that are related to the clash of the two regulations referred to as reality, then the prescription that must be recommended first is which rules must apply to resolve problems that arise.

If referring to the principle of pacta sunt servanda, as the principle of International Law that has been applied as an International Customary Law, then for Indonesia who is a member of the WTO and agrees to integrate itself into The Final Act, of course, must comply with the obligations that arise from the implementation of said regulation. If Indonesia as a member country does not carry out its obligations and makes other policies that are not in line with The Final Act, then the Indonesian government will be considered to violate the principle of pacta sunt servanda. As a result, Indonesia as a violator of The Final Act can be sued by other World Trade Organization (WTO) member countries who feel disadvantaged by the existence of the Law. Claims can be submitted through the WTO Disputes Settlement Body. Disputes Settlement Body has the authority to form a panel that will functionally settle the case, ratify the decision of the Panel (first level dispute resolution) and Appelate Body as an institution of appeal dispute resolution. In addition, the Disputes Settlement Body is also authorized to monitor the implementation of the Dispute Settlement Body decision.

\section{Disputes Settlement Body: Its Capacity and Authority}

Dispute Settlement Body in its capacity and authority resolves problems between the state authorities to decide disputes between member countries. The decision from the Dispute Settlement Body can contain strict orders to revoke member countries' trade policies that are not in line with the WTO stipulated provisions and orders that require violating countries to pay compensation as a result of losses suffered by other member countries. If the contents of a decision that has been determined in reality are not complied with by the offending country charged with liability, then the disadvantaged country may delay the concession or carry out obligations towards the offending country.

In the context of disharmony between Labor Laws and GATS, then in the event that there is a WTO member country that feels disadvantaged by the substance of the Labor Laws, eligible is legally required to file a claim. If the claim is granted by GATS, then one of the things that can be decided by GATS is ordering Indonesia to revoke the foreign workers placement policy in Indonesia (as contained in the Labor Laws). In fact, more than that, if the implementation of the Law in fact causes material losses to the suing country, Indonesia could be ordered to pay for the losses suffered by the plaintiff's state.

One principle that has important and fundamental relevance to this problem is the principle of lex posteriori legi priori. If this principle is applied, then the applicable force of Law Number 7 of 1994 should be negated or ignored by the Law. Both of these laws have an equal position, while this Law is a newer law. These newer laws can negate longer legislation. However, if it is seen that Law Number 7 of 1994 was born as a manifestation of international commitment, which in the end the country violated it, the potential for other countries to show distrust of the violating country emerged. In a concrete and serious level, it is possible for violating countries to accept the pressure of international sanctions in the form of exclusion from the international relations community.

In order to deal with all possibilities as described above, it is time for Indonesia to rush to evaluate the Labor Laws as well as revise the regulation, as well as compile implementation regulations that are in line with the provisions of free trade and do not conflict with GATS. Based on the understanding in the perspective of economic interest, the Indonesian government through its laws and regulations must be able to compromise with international commitments as a necessity that cannot be denied. 


\section{Regulating Foreign Workers in the Framework of National Interests}

The largest human resource statistics are owned by Indonesia. The 2015 population census obtained data that the population of Indonesia amounted to 254.9 million people with a population growth rate of 1.49 per year. This number positions Indonesia as third in the world after China and India (http://beritasore.com/2015/11/21/ jumlah- penduduk-indonesia-berpotensi terbesar -ketiga - sedunia/, terakhir diakses pada tanggal 1 September 2017.). This is a big capital in running the economy from the aspect of employment and marketing of manufactured goods. However, from such a large population it is still far from the amount that is appropriate for the population figure which is the productive force for work.

There are several estimates on this matter. First, employment that is still lacking so that it cannot accommodate the growth of the workforce. Second, the level of ability and education that is still low results in competitiveness which is also low. The current real condition, in the perspective of a market economy that operates industrialization, especially in developing countries, requires the important role of the government to implement social policies in terms of protecting and guaranteeing employment problems. The state must be able to control total policies in the field of labor to protect every workforce in all positions occupied freely in order to build their welfare.

Until now, an important issue that is ahead of Indonesia is the gap in competence. Comparatively, elementary school graduates are $45.13 \%$ of the population, while workers with a bachelor's degree and above are no more than $8.29 \%$. The reality of this gap in the competency of workers in turn creates conditions for workers who are vulnerable to various issues. Therefore protection of labor is really an urgent issue which is balanced with efforts to open more open and wide employment opportunities. Such reality is a space that should be considered in the formation of legal rules in two interests, namely the protection of domestic workers by continuing to open the space for foreign workers as a form of consistency in international commitments.

Regulating new form of foreign worker legislation is expected that the policies made and prepared can be realized certainty, justice and benefits for the workforce as a solution. Policies that are oriented to regulating, guiding and supervising efforts are aimed at a variety of labor-related activities. Regulations, guidance, and supervision carried out based on legislation will have to be in line with the dynamics of the development of increasingly rapid development so that its implementation is able to answer the demands of planning needs for the expansion and protection of workers, including guidance in aspects of industrial relations.

In the framework of future legal development concerning the establishment of laws and regulations concerning foreign workers, the principles of legal objectives must be accommodated. One of the principles in question is certainty, especially concerning the rules of written law. As it is known that law without the value of certainty, experiences a distortion of meaning and identity, because it no longer reflects its function as a code of conduct. Certainty is basically one of the pillars of the purpose of law. Legal certainty in this case also involves coherence in the legal system. Moreover, in the perspective of the economic interests of international trade, the law should open a space for compromise with international commitments without negating the substance oriented to the vision of the law itself.

\section{Concluding Remarks: Aligning International Commitments in National Interest}

Normatively the substance of the regulation of foreign workers contained in Law No. 13 of 2003 contains quite a problem as a legal problem that triggers uncertainty, considering the use of the term foreign workers does not necessarily cover the existence of foreign workers who are bound by work relations. With the Ratification of the Agreement Establishing the World Trade Organization or the Approval of the Establishment of a World Trade Organization through Law No. 7 of 1994 namely the Ratification of the WTO, Indonesia has established itself to carry out non-discriminatory and more free international trade activities. The consequence of the involvement of Indonesia as a WTO member 
country is that Indonesia must change the mindset of a single jurisdiction that has full sovereignty over trade policy, becoming an entity that must pay attention to the balance of treatment of other countries in conducting trade activities. The change in mindset is based on two main principles in world trade, namely Most Favored Nation (MFN) and National Treatment. The realization of the intended mindset, the formation of legislation related to the context of the problem which must heed International commitments, then the legislation in question must not conflict with international commitments.

The establishment of legislation concerning foreign workers in the future must functionally position the law as a tool to build the competence of local workforce in order to have competitiveness against foreign workers, in addition to the substance of its regulation, it should not be contrary to international commitments. In light of the fact that Indonesia is still in need of foreign investment, while at the same time remembering the influence that places Indonesia as a member of the WTO membership community, of course Indonesia must open opportunities and opportunities for foreign workers to enter. In order to safeguard policies as a legal consequence, a legal rule is needed that can functionally provide protection to domestic workers without having to contradict international commitments regarding the entry of foreign workers. Regarding the perception that Law No. 13 of 2003 does not adequately accommodate the various problems of the presence of foreign workers in Indonesia, as a manifestation of the implementation of the use of foreign workers, it is necessary to form a new law that specifically regulates foreign workers along with the employment relations that occur, including foreign workers with independent professions.

\section{References}

Abdul-Aziz, A. R. (2001). Foreign workers and labour segmentation in Malaysia's construction industry. Construction Management and Economics, 19(8), 789-798.

Abdul-Rahman, H., Wang, C., Wood, L. C., \& Low, S. F. (2012). Negative impact induced by foreign workers: Evidence in Malaysian construction sector. Habitat International, 36(4), 433-443.

Amengual, M., \& Chirot, L. (2016). Reinforcing the state: Transnational and state labor regulation in Indonesia. ILR Review, 69(5), 1056-1080.

Boswell, C., \& Straubhaar, T. (2004). The illegal employment of foreign workers: An overview. Intereconomics, 39(1), 4-7.

Chin, C. B. (1997). Walls of silence and late twentieth century representations of the foreign female domestic worker: the case of Filipina and Indonesian female servants in Malaysia. International Migration Review, 31(2), 353385.

Cohen, R. (2016). Migration and its enemies: Global capital, migrant labour and the nation-state. Routledge.

Elias, J. (2018). Governing Domestic Worker Migration in Southeast Asia: Public-Private Partnerships, Regulatory Grey Zones and the Household. Journal of Contemporary Asia, 48(2), 278-300.

Fong, P. E. (1992). Absorbing temporary foreign workers: the experience of Singapore. Asian and Pacific Migration Journal, 1(3-4), 495-509.

Herbert, W. (2010). Foreign workers and law enforcement in Japan. Routledge.

https://www.ilo.org/wcmsp5/groups/public/---asia/---ro-bangkok/documents/meetingdocument/wcms_623978.pdf

https://www.indonesia-investments.com/id/news/news-columns/foreign-workers-in-indonesia-a-threat-or-tacticto-gain-votes/item879o?

Hugo, G. (1993). Indonesian labour migration to Malaysia: trends and policy implications. Southeast Asian Journal of Social Science, 21(1), 36-70.

Kanapathy, V. (2006, December). Migrant workers in Malaysia: an overview. In Country paper prepared for Workshop on East Asian Cooperation Framework for Migrant Labour, Kuala Lumpur. http://www. isis. org. my/files/pubs/papers/VK_migration-Neat_6Deco6. Pdf. Accessed 22 September 2019)

Kapiszewski, A. (2017). Arab versus Asian migrant workers in the GCC countries. In South Asian Migration to Gulf Countries (pp. 66-9o). Routledge India.

Kaur, A. (2005). Indonesian migrant workers in Malaysia: from preferred migrants to'last to be hired'workers. RIMA: Review of Indonesian and Malaysian Affairs, 39(2), 3.

Killias, O. (2010). 'Illegal'migration as resistance: Legality, morality and coercion in Indonesian domestic worker migration to Malaysia. Asian Journal of Social Science, 38(6), 897-914. 
Kim, J. (2003). Insurgency and advocacy: Unauthorized foreign workers and civil society in South Korea. Asian and Pacific Migration Journal, 12(3), 237-269.

Lie, J. (1994). The "problem" of foreign workers in contemporary Japan. Bulletin of Concerned Asian Scholars, 26(3), 3-11.

Liow, J. (2003). Malaysia's illegal Indonesian migrant labour problem: In search of solutions. Contemporary Southeast Asia: A Journal of International and Strategic Affairs, 25(1), 44-64.

Liow, J. C. (2017). Malaysia's approach to Indonesian migrant labor: Securitization, politics, or catharsis?. In NonTraditional Security in Asia (pp. 52-77). Routledge.

Noor, Z. M., Isa, N., Said, R., \& Jalil, S. A. (2011). The impact of foreign workers on labour productivity in Malaysian manufacturing sector.

Salleh, N. A. B., Nordin, N. B. M., \& Rashid, A. K. B. A. (2012). The language problem issue among foreign workers in the Malaysian construction industry. International Journal of Business and Social Science, 3(11).

Yamanaka, K. (1993). New immigration policy and unskilled foreign workers in Japan. Pacific Affairs, 72-9o.

Yen, K. C., Platt, M., Yeoh, B. S., \& Lam, T. (2015). Structural Conditions and Agency in Migrant Decision-Making: A Case of Domestic and Construction Workers from Java, Indonesia. Sussex: Migrating out of Poverty Research Programme Consortium. 